Original Research Paper

\title{
Experimental Investigation of Thermo-Physical Properties of Soil Using Solarisation Technology
}

\author{
${ }^{1,2}$ Ahmed Abed Gatea Al-Shammary, ${ }^{1}$ Abbas Kouzani, \\ ${ }^{1}$ Akif Kaynak, ${ }^{1}$ Sui Yang Khoo and ${ }^{1}$ Michael Norton \\ ${ }^{1}$ School of Engineering, Deakin University, Geelong, VIC 3216, Australia \\ ${ }^{2}$ Departments of Soil Science and Water Resources, College of Agriculture, University of Wasit, Kut, Iraq
}

\author{
Article history \\ Received: 19-04-2017 \\ Revised: 10-06-2017 \\ Accepted:17-07-2017 \\ Corresponding Author: \\ Ahmed Abed Gatea \\ Al-Shammary \\ School of Engineering, Deakin \\ University, Geelong, VIC 3216, \\ Australia \\ Tel: $+61-3-52272818$ \\ Mobile: $+61-434096831$ \\ Fax: +61-3-52272167 \\ Email: agatea@deakin.edu.au
}

\begin{abstract}
Soil Thermo-Physical Properties (TPP) depend on heat transfer in the soil. This paper presents a study on different soil solarisation technologies influenced by soil TPP. This study evaluates three factors: The tillage depth for soil at three levels $(15,25$ and $45 \mathrm{~cm})$, the number of plastic film at three levels (single, double and without plastic film) and three cases of fertilizers (chemical fertilizer, organic fertilizer and without fertilizer). The parameters explored in this study include soil bulk density $\left(\mathrm{Mg} / \mathrm{cm}^{3}\right)$, soil porosity $(\%)$, soil volumetric moisture content $\left(\mathrm{cm}^{3} / \mathrm{cm}^{3}\right)$ and soil thermal diffusivity $\left(\mathrm{m}^{2} / \mathrm{sec}\right)$. Data management and analysis were performed using SAS 9.1 statistical software and the spilt-plot under Randomized Complete Block Design (RCBD). The results show that soil Tillage Depth (TD) strongly influences TPP, as well as a significant effect on soil bulk density $\left(\rho_{b}\right)$, porosity $(\Phi)$, volumetric moisture content $(\theta)$ and thermal diffusivity $(D)$. The results also reveal that a tillage depth of $15 \mathrm{~cm}$ produces lower values of $\rho_{b}, \theta$ and $D\left(1.25 \mathrm{Mg} / \mathrm{cm}^{3}, 0.131 \mathrm{~cm}^{3} / \mathrm{cm}^{3}\right.$ and $1.24 \times 10^{-6} \mathrm{~m}^{2} / \mathrm{sec}$, respectively) and a higher value of $\Phi(52.78 \%)$. In addition, the finding indicates that $\rho_{b}$ is increased by increasing TD. There was a significant positive correlation between the number of plastic film and parameters studied. The soil double plastic film produced lower values of $\rho_{b}$ and $D$ for soil $\left(1.253 \mathrm{Mg} / \mathrm{cm}^{3,} 7.76 \times 10^{-7} \mathrm{~m}^{2} / \mathrm{sec}\right)$. However, it recorded higher values for $\Phi$ and $\theta$ for soil $\left(52.70 \%\right.$ and $0.231 \mathrm{~cm}^{3} / \mathrm{cm}^{3}$, respectively). Furthermore, the current study shows significant differences between the types of fertilizers on $\rho_{b}$. Organic Fertilizer (OF) obtained a lower value of $\rho_{b}\left(1.2 \mathrm{Mg} / \mathrm{m}^{3}\right)$, compared with chemical fertilizer and without fertilizer (1.28 and $1.31 \mathrm{Mg} / \mathrm{m}^{3}$, respectively). In contrast, contrary to expectations, this study did not find significant differences between the types of fertilizer on $D$ and $\theta$ for soil. A positive correlation was found in the interaction between the studied factors in the parameters. Furthermore, $D$ increased with increasing soil bulk density $(p b)$ and tillage depth.
\end{abstract}

Keywords: Soil Tillage Depth, Number of Plastic Film, Organic Fertilizer, Soil Bulk Density, Soil Thermal Diffusivity

\section{Introduction}

Soil Thermo-Physical Properties (TPP) are widely used parameters of soil physics in the field of agricultural and especially in applications concerning soil energy balance (Alrtimi et al., 2016; An et al., 2016; Andújar Márquez et al., 2016; Genesio et al., 2012; Logsdon et al., 2010; Rajeev and Kodikara, 2016; Ravazzani et al., 2015; Usowicz et al., 2016; Wu et al.,
2017; Xiukang et al., 2015). Consequently, knowledge of TPP is required to accurately predict soil temperature (Hu et al., 2016). Soil Solarisation Technology (SST) is an important practical method of increasing soil temperature by using solar radiation, playing a key role in improving and controlling soil properties, including in crop fields (Keesstra et al., 2016; Moreno et al., 2016). SST is also the main factor for analysing Organic Matter (OM) in soil (Conant et al., 2011; Grunwald et al., 2017; 
Li et al., 2016). Furthermore, SST overpowers weed growth (Kader et al., 2017; Mutetwa and Mtaita, 2014). SST strongly affects the establishment of microclimates that lead to increased fertilizer productivity in soil, reduces soil irrigation consumption (Cerdà et al., 2016; Jiang et al., 2017; Mahdavi et al., 2017; Wu et al., 2017; Zhou et al., 2017), affects soil temperature (Al-Shammary and Al-Sadoon, 2014; Al-Shammary et al., 2016) and improves the physical structure of soil (Dec et al., 2009).

Soil Thermo-Physical Properties (TPP) are soil thermal conductivity $(k)$, volumetric heat capacity $\left(C_{v}\right)$ and thermal diffusivity $(D)$. They strongly depend on soil bulk density $\left(\rho_{b}\right)$, porosity $(\Phi)$ and gravimetric water content $(\theta)$ for soil (Alrtimi et al., 2016; Levy and Schmidtm, 2016; Lu and Dong, 2015; Mondal et al., 2016; Ravazzani, 2017; Usowicz et al., 2013; Zhang et al., 2017). There are several studies in the literature that estimate TPP under different conditions.

Williams et al. (2016) observed that the relationship between soil tillage management and hydrothermal properties influences soil structure and increases crop production. In addition, Al-Shammary and Al-Sadoon (2014) reported a significant differences between tillage depth and soil thermal properties. Their results show that thermal conductivity $(K)$ is increased with increasing soil depth. Consequently, increasing $\rho_{b}$ and water content $(w)$ with increasing TD.

Other studies Chaudhari et al. (2013); Li et al. (2017); Merante et al. (2017) have found that Organic Fertilizer (OF) can improve soil physical properties. OF has a positive effect on soil bulk density $(\rho b)$ and porosity $(\Phi)$ because improving soil biological fertility. Celik et al. (2010); Li et al. (2017) studied the effects of Organic Fertilizer (OF) on SPP. They noted that $\mathrm{OF}$ significantly reduced soil bulk density $(p b)$. Therefore, OF can help improving soil structure as well as $\rho b$ depend on different factors, For example, compaction, consolidation and the amount of organic matter present in the soil. Furthermore, Pires et al. (2017); Alam and Salahin (2013) indicated that soil porosity $(\Phi)$ is influenced by the tillage system. They found that soil porosity decreases with soil depth.

Liang et al. (2017) Qin et al. (2015); Xiukang et al. (2015); Jabran et al. (2016); Wu et al. (2017); Ingman et al. (2015) all found that Soil-Mulching Systems (SMS) had a positively influence on soil heat transfer and soil evaporation. As a result, $S M S$ was more useful for reducing soil moisture losses. They observed also that SMS reduces the temperature of the soil.

Soil thermal conductivity $(K)$ depends on $(\rho b),(\Phi)$ and ( $\theta$ ) (Lydżba et al., 2016; Tokoro et al., 2016), as well as Soil Mineral Composition (SMC) and texture (Tokoro et al., 2016). Usowicz et al. (2013); Pramanik et al. (2015) found that Soil Solarisation Technology (SST) had a positively impact on soil temperature because It influenced the soil thermal regime by controlling for radiation balance and soil thermal conductivity $(K)$, as well as volumetric heat capacity $\left(C_{v}\right)$ in soil.

Ingman et al. (2015); Merante et al. (2017); Roxy et al. (2014); Gan et al. (2012) demonstrated that the $K$ and $C_{v}$ of soil are significantly impacted by soil moisture content. Furthermore, the results of their study identified increased $K$ and $C_{v}$ with soil depth. Jabro et al. (2016); Chaudhari et al. (2013) demonstrated that soil Tillage Depth (TD) has an influence on soil physical properties. They found that $\rho b$ was significantly increased by soil TD. In contrast, other studies presented the contradictory result that tillage depth made no significant difference to $\rho b$ (Jabro et al., 2016; Karuma et al., 2014).

Gnatowski (2009); Levy and Schmidt (2016) found that soil thermal diffusivity $(D)$ is a fundamental property for studying the thermal process of soil. The results of their study indicate that $D$ depends on moisture content because $D$ is increased by increasing volumetric moisture content in soil. Tong et al. (2017) argued that $D$ is related to soil temperature changes. Their results indicated that $D$ depended on soil thermal conductivity $(K)$. Miyajima et al. (2015); Usowicz et al. (2016); Roxy et al. (2014) showed that soil thermal diffusivity $(D)$ is amplified by increasing the soil bulk density and moisture content. However, Makarychev and Bolotov (2017) observed that soil thermal diffusivity $(D)$ is decreased by increasing moisture content. Levy and Schmidt (2016) discovered that soil thermal diffusivity $(D)$ significantly increased with increasing soil depth.

The objective of this study is to investigate the effect of soil solarisation technology on soil thermal diffusivity. Furthermore, the study examines the influence of soil tillage depth, number of plastic films and fertilizer type son soil bulk density, soil volumetric moisture content and soil porosity.

\section{Materials and Methods}

The field experiment involved studying a soil solarisation technology influenced by some soil thermalphysical properties: Soil bulk density $(\rho b)$, porosity $(\Phi)$, gravimetric water content $(\theta)$ and soil thermal diffusivity $(D)$ for Silty Clay (SIC). Soil specifications are shown in Table 1. The research procedure involved several steps. Firstly, the field allocated to the study experiments was cleared of plant waste and then soil samples for silty clay were used to blend the tissue from the continuous field with a three depths $(0-15,15-25$ and $25-45 \mathrm{~cm})$ after smoothing and passing it through a $2 \mathrm{~mm}$ diameter sieve and drying it under the sun. Several models were used to analyse the physical and chemical properties of the soil, Soil Mechanical Analysis has classified under (Triangular diagram) according to the "Modern American Classification "the procedure used by (Vogt et al., 2015), Soil texture was determined by hydrother meter method 
and the Electric Conductivity (EC) was done according to the procedure of (Krishna, 2016), $\mathrm{Ph}$ soil was prepared according to the procedure used by (Vogt et al., 2015), Organic matter by (Kroetsch and Wang, 2007). For the experiments, three factors were selected: (i) Three soil depths for tillage systems $(15,25$ and $45 \mathrm{~cm})$, (ii) Three levels for number of plastic films(single, double and without-plastic film) and (iii) Three fertilizer types (chemical fertilizer type $\left[0.07 \mathrm{~kg} / 2 \mathrm{~m}^{2}\right.$ Triple Superphosphate TSP added, equivalent to $350 \mathrm{~kg} / \mathrm{ha}$, organic fertilizer $\left[0.05 \mathrm{~kg} / 2 \mathrm{~m}^{2}\right.$ humic acid added, equivalent to $250 \mathrm{~kg} / \mathrm{ha}$ ] and without fertilizer). Each treatment area was $2 \mathrm{~m}^{2}$, making a total experiment area of $162 \mathrm{~m}^{2}$. The experiment included 27 treatments $\times 3$ replicates, making a total of 81 experimental treatment units, as shown in Fig. 1. The procedures of this study were tested by analysis of variance and least significant differences were compared averages at a probability the $5 \%$ level using a split-split plot under the randomized Complete Block Design (RCBD). In addition, the study used a tractor Same Explorer 85 DT and Disc Plough for the purpose of ploughing to three level depths $(15,25$ and $45 \mathrm{~cm})$ and then disc harrows to smooth the soil as shown (Appendix 2 and 3). In the next step, the experimental field was irrigated to full capacity $(100 \%)$ by using surface Irrigation method. The experimental field unit was covered with plastic films (single, double) after $48 \mathrm{~h}$ from irrigation process. Transparent polyethylene film was used for soil solarisation technology, which was $0.5 \mathrm{~mm}$ thick, $600 \mathrm{~mm}$ width. It is proven by the polyethylene film with the soil surface, it has been properly rolled so that it is perfectly attached to the soil surface purpose increasing solarisation efficiency and Wear plastic straps at least two places to prevent dusting. Finally, calculations of soil bulk density $\left(\mathrm{Mg} / \mathrm{m}^{3}\right)$, soil porosity $(\%)$, soil volumetric moisture content $\left(\mathrm{cm}^{3} / \mathrm{cm}^{3}\right)$ and soil thermal Diffusivity $(D)$ were carried out after removing the covers from all three treatment areas. Analysis of Variance (ANOVA table) for parameter studied represented by mean square error (appendix 1).

\section{Mathematical Calculations}

\section{Soil Bulk Density, Porosity and Volumetric Moisture Content}

Soil bulk density $(\rho b)$ was measured by the volumetric cylinder method. With this method, a cylindrical metal sampler with a removable sample cylinder that fits inside it was pressed into the soil to depths of 15,25 and $45 \mathrm{~cm}$ and carefully removed to preserve a known volume of soil in the cylindrical sample with a height of $7 \mathrm{~cm}$ and a diameter $5 \mathrm{~cm}$. The soil sample was dried at $105^{\circ} \mathrm{C}$ for $24 \mathrm{~h}$ and then weighed. Bulk density $(\rho b)$ is the oven-dried mass $\left(m_{s}\right)$ divided by the field volume of the sample $\left(v_{t}\right)$, as shown in the following equation (Smith, 2000):

$$
\text { Bulk density }(\rho b)=\frac{M_{s}\left(M_{g}\right)}{V_{t}\left(m^{3}\right)}
$$

where, $M_{s}$ is the oven dry weight of soil $(M g)$ and $V_{t}$ is the volume of soil sample $\left(\mathrm{m}^{3}\right)$.

Total porosity $(\Phi)$ is defined as the percentage of the bulk volume not occupied by solids, calculated by the following equation (Smith, 2000):

$$
\operatorname{Porosity}(\phi)=1-\frac{\rho p\left(\frac{M_{g}}{m^{3}}\right)}{D_{p}\left(\frac{M_{g}}{m^{3}}\right)}
$$

where, $\rho b$ is soil bulk density $\left(\mathrm{Mg} / \mathrm{m}^{3}\right)$ and $D_{P}$ is soil particle density $\left(\mathrm{Mg} / \mathrm{m}^{3}\right)$.

Furthermore, the volumetric moisture content $\left(\mathrm{cm}^{3} / \mathrm{cm}^{3}\right)$ was calculated by gravimetric methods $\left(p_{w}\right)$ of field soil at a depth of $0-45 \mathrm{~cm}$. This involved first weighing the wet samples of all treatments and then oven-drying the samples at $105^{\circ} \mathrm{C}$ for $24 \mathrm{~h}$. The moisture percentage in the soil samples $\left(p_{w}\right)$ on a wet-dry mass basis was obtained by dividing the difference between the wet and dry samples and multiplying by 100 . Where the bulk density $(\rho b)$ of a sample is known, the volumebasis water content $(\theta)$ may be obtained by the following equation (Smith, 2000):

$$
\text { Volumertic moisturecontent }(\theta)=\frac{p_{w}^{*} p_{b}}{p_{w}}
$$

where, $\theta$ is the volumetric moisture content $\left(\mathrm{cm}^{3} / \mathrm{cm}^{3}\right), \rho_{w}$ is the moisture content by weight $(\%), \rho_{b}$ is the soil bulk density $\left(\mathrm{Mg} / \mathrm{m}^{3}\right)$ and $\rho_{w}$ is the water density $\left(\mathrm{Mg} / \mathrm{m}^{3}\right)$.

\section{Soil Thermal Diffusivity $\left(\mathrm{m}^{2} / \mathrm{sec}\right)$ :}

\section{Soil Thermal Conductivity (W/mk)}

The soil thermal conductivity $(K)$ of silt clay was calculated by using the following equation (Kersten, 1949):

$$
K=[0.9 \log w-0.2] 10^{0.01 \gamma d}
$$

where, $w$ is the moisture content $(\%)$ and $\gamma$ is the dry density $\left(\mathrm{gm} / \mathrm{cm}^{3}\right)$.

\section{Soil Volumetric Heat Capacity $\left(\mathrm{J} / \mathrm{m}^{3} \mathrm{k}\right)$}

The soil volumetric heat capacity $\left(C_{v}\right)$ was calculated with reasonable accuracy from the volumetric water content $(\theta)$ and soil bulk density $(\rho b)$ (Evett et al., 2012):

$$
C v=\frac{2.01 \times 10^{6} p_{b}}{2.65+4.19 \times 10^{6} \theta}
$$




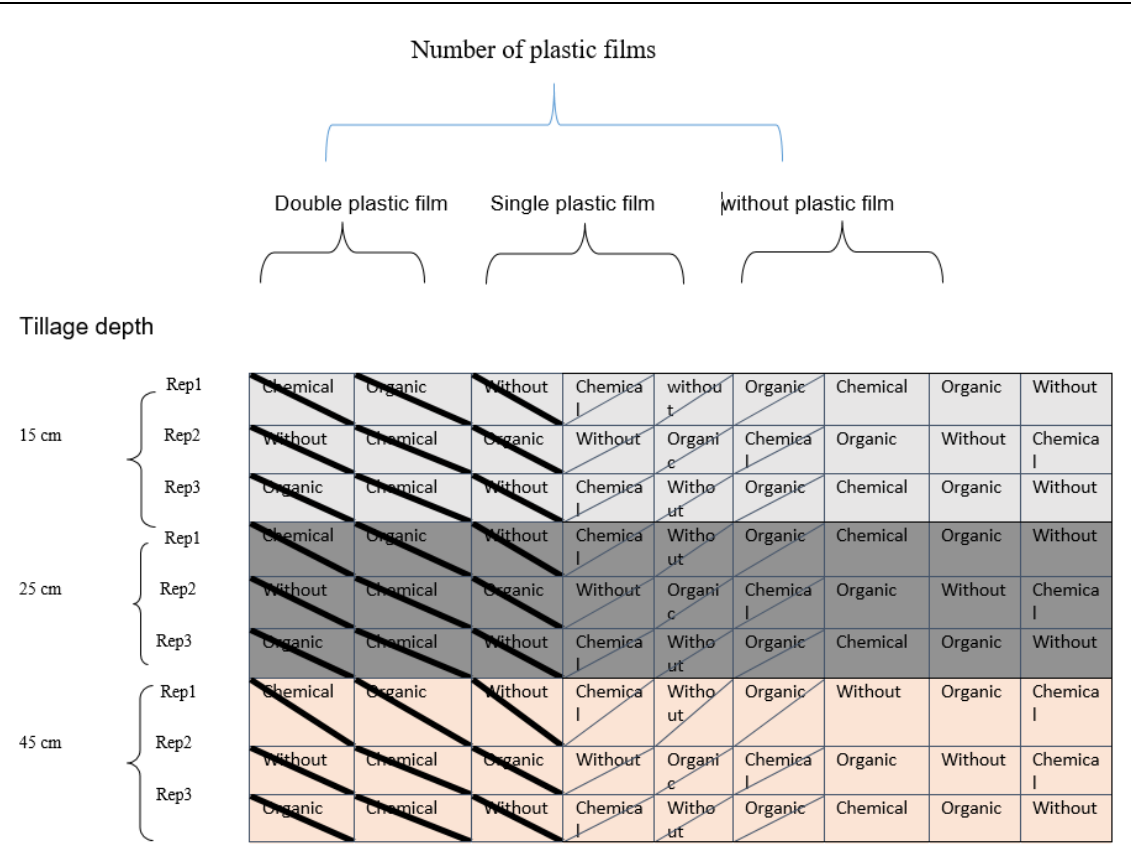

Fig. 1. Schematic diagram of the experimental field design

Table 1. Characterization of soil profile.

\begin{tabular}{|c|c|c|c|c|c|c|c|c|c|c|}
\hline \multirow[b]{4}{*}{$\begin{array}{l}\text { Depth of } \\
\text { soil }(\mathrm{cm})\end{array}$} & \multicolumn{10}{|c|}{ Soil properties } \\
\hline & \multicolumn{10}{|l|}{ Physical } \\
\hline & \multirow[b]{2}{*}{$\begin{array}{l}\text { Bulk density } \\
\left(\mathrm{Mg} / \mathrm{cm}^{3}\right)\end{array}$} & \multirow[b]{2}{*}{$\begin{array}{l}\text { Porosity } \\
(\%)\end{array}$} & \multicolumn{3}{|c|}{$\begin{array}{l}\text { Soil mechanical analysis } \\
\text { Silty Clay (SIC) }\end{array}$} & \multicolumn{5}{|c|}{ Chemical } \\
\hline & & & $\begin{array}{l}\text { Silt } \\
\mathrm{gm} / \mathrm{kg}\end{array}$ & $\begin{array}{l}\text { Clay } \\
\mathrm{gm} / \mathrm{kg}\end{array}$ & $\begin{array}{l}\text { Sand } \\
\mathrm{gm} / \mathrm{kg}\end{array}$ & $\mathrm{ph}$ & $\mathrm{EC} \mathrm{ds/m}$ & $\begin{array}{l}\mathrm{N} \\
\mathrm{Mg} / \mathrm{kg}\end{array}$ & $\begin{array}{l}\mathrm{P} \\
\mathrm{Mg} / \mathrm{kg}\end{array}$ & $\begin{array}{l}\mathrm{K} \\
\mathrm{Mg} / \mathrm{kg}\end{array}$ \\
\hline $0-15$ & 1.31 & 50.49 & 407 & 468 & 125 & 6.90 & 2.63 & 30.63 & 7.54 & 407.20 \\
\hline $15-25$ & 1.33 & 49.66 & 408 & 454 & 138 & 6.82 & 3.82 & 27.50 & 10.00 & 420.40 \\
\hline $25-45$ & 1.38 & 47.88 & 426 & 412 & 162 & 6.58 & 3.95 & 25.56 & 10.00 & 430.50 \\
\hline
\end{tabular}

\section{Soil Thermal Diffusivity $\left(\mathrm{m}^{2} / \mathrm{sec}\right)$}

Soil diffusivity is defined as the ratio of thermal conductivity to volumetric heat capacity (Hillelm, 1998):

$$
D=\frac{K}{C_{v}}
$$

where, $D$ is the soil thermal diffusivity $\left(\mathrm{m}^{2} / \mathrm{sec}\right), K$ is the thermal conductivity $(\mathrm{W} / \mathrm{mK})$ and $C_{v}$ is the volumetric heat capacity $\left(\mathrm{J} / \mathrm{m}^{3} \mathrm{k}\right)$.

\section{Results and Discussion}

\section{Influence of the Studied Factors on Soil Bulk Density $\left(\mathrm{Mg} / \mathrm{m}^{3}\right)$}

Table 2 shows the influence of soil Tillage Depth (TD), number of Plastic Films (PF) and Fertilizer Type (FT) on the soil bulk density $(\rho b)$. The results show a significant difference in tillage depth in soil bulk density.
The soil bulk density increased from 1.25 to 1.27 $\mathrm{Mg} / \mathrm{cm}^{3}$ when increasing soil TD from 15 to $25 \mathrm{~cm}$. The increasing rate was $16.8 \%$. $\rho b$ also increased to 1.31 $\mathrm{Mg} / \mathrm{cm}^{3}$ at an increasing rate of $36 \%$ and an increasing tillage depth of $45 \mathrm{~cm}$. This result may be due to the gradual increase in soil bulk density with increasing soil depth. These results match those observed by (Bennett et al., 2017; Keesstra et al., 2016; Tamminen and Starr, 1994; Romaneckas et al., 2009).

The number of Plastic Films (PF) caused significant variation in $\rho b$. The double-plastic films treatment produced the lowest soil bulk density $\left(1.25 \mathrm{Mg} / \mathrm{cm}^{3}\right)$ compared with the single-plastic films and without plastic films treatments $\left(1.27,1.31 \mathrm{Mg} / \mathrm{m}^{3}\right.$, respectively). The reason for this result may be twofold: the increasing soil temperature at the soil surface and the decomposition of organic fertilizer by microorganisms, which would decrease soil bulk density compared with single-plastic films and without plastic films. This finding is in agreement with (Conant et al., 2011; Al-Shammary et al., 2016; Li et al., 2016; Grunwald et al., 2017). 


\begin{tabular}{|c|c|c|c|c|c|}
\hline \multirow{2}{*}{$\begin{array}{l}\text { Tillage Depth } \\
\text { (cm) (TD) }\end{array}$} & \multirow{2}{*}{$\begin{array}{l}\text { Number of Plastic } \\
\text { Films (PF) }\end{array}$} & \multicolumn{3}{|c|}{$\begin{array}{l}\text { Average } \rho_{b}\left(\mathrm{Mg} / \mathrm{m}^{3}\right) \text { on interaction triple } \\
\text { Fertilizer Type }(\mathrm{FT})\end{array}$} & \multirow{2}{*}{$\begin{array}{l}\text { Interaction tillage depth and } \\
\text { number of plastic films }\end{array}$} \\
\hline & & Chemical & Organic & Without & \\
\hline \multirow[t]{4}{*}{15} & Single & 1.25 & 1.22 & 1.26 & 1.24 \\
\hline & Double & 1.24 & 1.20 & 1.25 & 1.23 \\
\hline & Without-plastic film & 1.28 & 1.26 & 1.29 & 1.27 \\
\hline & Single & 1.28 & 1.26 & 1.30 & 1.28 \\
\hline \multirow[t]{2}{*}{25} & Double & 1.25 & 1.23 & 1.30 & 1.26 \\
\hline & Without-plastic film & 1.28 & 1.26 & 1.30 & 1.28 \\
\hline \multirow[t]{3}{*}{45} & Single & 1.28 & 1.27 & 1.36 & 1.27 \\
\hline & Double & 1.24 & 1.24 & 1.32 & 1.25 \\
\hline & Without-plastic film & 1.37 & 1.37 & 1.38 & 1.31 \\
\hline \multicolumn{2}{|c|}{ Average of fertilizer type } & 1.27 & 1.25 & 1.30 & LSD 0.05 \\
\hline \multirow[t]{4}{*}{$\begin{array}{l}\text { Tillage Depth } \\
(\mathrm{cm})(\mathrm{TD})\end{array}$} & Fertilizer Type (FT) & $\begin{array}{l}\text { Average } \rho_{b}\left(\mathrm{Mg} / \mathrm{m}^{3}\right) \\
\text { on Interaction }\end{array}$ & $\begin{array}{l}\text { Average } \\
\text { on Tillag }\end{array}$ & $\begin{array}{l}\left.\mathrm{g} / \mathrm{m}^{3}\right) \\
\text { th }(\mathrm{TD})\end{array}$ & $\begin{array}{l}\text { Tillage depth }=0.025 \text {, } \\
\text { Number of plastic }\end{array}$ \\
\hline & & Tillage Depth and & & & Films $=0.025$ \\
\hline & & Fertilizer Type & & & Fertilizer Type $=0.025$ \\
\hline & & & & & Tillage depth X \\
\hline \multirow[t]{3}{*}{15} & Chemical & 1.25 & & 1.25 & Number of plastic \\
\hline & Organic & 1.22 & & & Films $=0.018$ \\
\hline & Without & 1.26 & & & Tillage depth X \\
\hline \multirow[t]{3}{*}{25} & Chemical & 1.27 & & 1.27 & Fertilizer $=0.018$ \\
\hline & Organic & 1.25 & & & $\begin{array}{l}\text { Number of plastic } \\
\text { Films X fertilizer }\end{array}$ \\
\hline & Without & 1.30 & & & Type $=0.026$ \\
\hline \multirow[t]{3}{*}{45} & Chemical & 1.30 & & 1.31 & Tillage depth X \\
\hline & Organic & 1.29 & & & Number of plastic \\
\hline & Without & 1.35 & & & Films X Fertilizer \\
\hline Films (PF) & Fertilizer Type (FT) & $\begin{array}{l}\text { Average } \rho_{b}\left(\mathrm{Mg} / \mathrm{m}^{3}\right) \\
\text { on Interaction of the } \\
\text { number of Plastic Films } \\
(\mathrm{PF}) \text { and fertilizer type }\end{array}$ & & $\begin{array}{l}\text { Average } \\
\text { the Numb }\end{array}$ & $\begin{array}{l}\text { Type }=0.006 \\
\left.\mathrm{Ig} / \mathrm{m}^{3}\right) \text { on } \\
\text { f Plastic Films }(\mathrm{PF})\end{array}$ \\
\hline \multirow[t]{3}{*}{ Single } & Chemical & 1.27 & 1.27 & & \\
\hline & Organic & 1.25 & & & \\
\hline & Without & 1.30 & & & \\
\hline \multirow[t]{3}{*}{ Double } & Chemical & 1.24 & 1.25 & & \\
\hline & Organic & 1.22 & & & \\
\hline & Without & 1.29 & & & \\
\hline \multirow{3}{*}{$\begin{array}{l}\text { Without-plastic } \\
\text { Film }\end{array}$} & Chemical & 1.31 & 1.31 & & \\
\hline & Organic & 1.29 & & & \\
\hline & Without & 1.32 & & & \\
\hline
\end{tabular}

A significant difference in soil bulk density $(\rho b)$ is obtained for fertiliser types. The soil with Organic Fertilizer (OF) showed a lower value of $\rho b\left(1.25 \mathrm{Mg} / \mathrm{m}^{3}\right)$ compared with Chemical Fertilizer (CF) and no Fertilizer (WF) $\left(1.27\right.$ and $1.30 \mathrm{Mg} / \mathrm{m}^{3}$, respectively). The reason for this result might be that the application of organic fertilizer normally reduces $\rho b$ of soil due to the higher organic matter content of the soil. These results agree with the findings of (Celik et al., 2010; Li et al., 2017), who reported the relevance of the application of organic matter to the improvement in physical and chemical properties of the soil. The interaction between Tillage Depth (TD) and number of Plastic Films (PF) showed a positive correlation in $\rho b$ values, with the lowest value of $\rho b$ showing at TD15 cm + double- plastic films at $1.23 \mathrm{Mg} / \mathrm{cm}^{3}$. In contrast, the highest $\rho b$ value $\left(1.31 \mathrm{Mg} / \mathrm{m}^{3}\right)$ was obtained by $\mathrm{TD} 45 \mathrm{~cm}+$ without-plastic films treatment. Further analysis showed that there was a significant difference in the interaction between TD and FT on soil bulk density $(\rho b)$. The lower average $\rho b\left(1.22 \mathrm{Mg} / \mathrm{m}^{3}\right)$ was obtainedforTD15 $\mathrm{cm}$ and Organic Fertilizer (OF) type, while the highest average $\rho b\left(1.35 \mathrm{Mg} / \mathrm{m}^{3}\right)$ was obtained for TD $45 \mathrm{~cm}$ and Without Fertilizer (WF) type. The results, as shown in Table 2, indicate a significant difference in the interaction between the number of Plastic Films (PF) and Fertilizer Type (FT) on soil bulk density $(\rho b)$. The lower value of $\rho b\left(1.22 \mathrm{Mg} / \mathrm{m}^{3}\right)$ was obtained between the double-plastic films and the Organic Fertilizer (OF) type, while the higher value of $\rho b\left(1.32 \mathrm{Mg} / \mathrm{m}^{3}\right)$ was obtained 
without-plastic films and Without Fertilizer (WF) type. Another important finding was that interactions between Tillage Depth (TD), number of Plastic Films (PF) and Fertilizer Type (FT) showed significant differences between treatments on $\rho b$. The lowest average for value $\rho b(1.20$ $\mathrm{Mg} / \mathrm{m}^{3}$ ) was obtained at the interaction between TD $15 \mathrm{~cm}$, double-plastic film and organic fertilizer, while the highest average value of $\rho b\left(1.38 \mathrm{Mg} / \mathrm{m}^{3}\right)$ was obtained at TD 45 $\mathrm{cm}$, without-plastic films and without fertilizer type.

\section{Influence of the Studied Factors on Soil Porosity (\%)}

Table 3 shows the experimental data for soil Tillage Depth (TD), number of Plastic Films (PF) and Fertilizer Type $(\mathrm{FT})$ on soil porosity $(\Phi)$. The results showed a significant difference between TD on $\Phi$. The highest value of $\Phi(52.78 \%)$ was obtained at TD15 $\mathrm{cm}$ in comparison withTD25 and $45 \mathrm{~cm}$, which showed the values of 51.86 and $50.30 \%$, respectively. The reason for this result might be the reduced soil porosity for increased bulk density when increasing tillage depth. This finding is in agreement with the result obtained by (Alam and Salahin, 2013). There was a significant positive correlation between numbers of Plastic Films $(\mathrm{PF})$ and soil porosity $(\Phi)$. The highest value of $\Phi$ $(52.70 \%)$ was obtained with the double-plastic films in comparison with the single-plastic films and without plastic films, which showed the values of 51.82 and $50.43 \%$ respectively. The reason for this finding may be that the soil of the double-plastic film has the lowest $p b$ compared with the soil of the single-plastic films and without plastic films. Another reason could be that the soil of the double-plastic film had high temperature storage for soil, which led to the decomposition of the organic fertilizer by microorganisms. This would have decreased soil bulk density and increased soil porosity, compared with other treatments, a finding that is in agreement with (Merante et al., 2017; Keesstra et al., 2016). Further analysis showed a significant difference in the effect of fertilizer type son soil porosity $(\Phi)$. The higher value of $\Phi(52.57 \%)$ was obtained with Organic Fertilizer (OF) in comparison with Chemical Fertilizer (CF) and Without Fertilizer (WF) (51.73 and 50.64\%, respectively). The reason for this result may be that the soil with organic fertilizer has a lower soil bulk density $(p b)$, which leads to increased porosity $(\Phi)$. These results agree with the findings of (Li et al., 2017; Merante et al., 2017), in which the increasing organic matter of the soil led to decreased bulk density $(p b)$ with increased porosity $(\Phi)$. The results in Table 3 show that there were significant differences in the interaction between Tillage Depth (TD) and the number of Plastic Films (PF) on the soil porosity $(\Phi)$. The TD15 cm and double-plastic film showed the highest $\Phi(53.70 \%)$; the lowest value of $\Phi$ $(48.92 \%)$ was obtained at TD $45 \mathrm{~cm}$ and without-plastic film. Furthermore, there was a strong evidence of interaction between TD and FT on $\Phi$, which showed the highest value of $\Phi(53.58 \%)$ at TD15 $\mathrm{cm}$ and Organic
Fertilizer (OF), while the lowest value of $\Phi(48.04 \%)$ was obtained at TD $45 \mathrm{~cm}$ and Without Fertilizer (WF). Also, the results show that the interaction between the number of Plastic Films (PF) and Fertilizer Types (FT) was significantly different. The highest value of $\Phi$ $(53.83 \%)$ was obtained for the interaction of the doubleplastic film and Organic Fertilizer (OF), while the lowest $\Phi(49.95 \%)$ was obtained for without-plastic film and Without Fertilizer (WF). Furthermore, the interaction between soil Tillage Depth (TD), number of Plastic Films (PF) and Fertilizer Type (FT) showed significant differences among treatments on $\Phi$, interaction between TD15 cm, the soil of the double-plastic film and organic fertilizer showed the highest value of $\Phi(54.71 \%)$, while the lowest $\Phi(47.92 \%)$ was obtained at TD $45 \mathrm{~cm}$, from the soil without-plastic film and two levels of fertilizer types Without Fertilizer (WF) and Organic Fertilizer (OF).

\section{Influence of the Studied Factors on Soil Volumetric Moisture Content $\left(\mathrm{cm}^{3} / \mathrm{cm}^{3}\right)$}

Table 4 presents the summary statistics for the influence of soil Tillage Depth (TD), number of Plastic Films (PF) and Fertilizer Types (FT) on the soil volumetric moisture content $(\theta)$. It can be seen that the Tillage Depth (TD) had a significant effect on $\theta$. TD 25 $\mathrm{cm}$ was obtained at a higher value of $\theta\left(0.196 \mathrm{~cm}^{3} / \mathrm{cm}^{3}\right)$, compared with TD 45 and $15 \mathrm{~cm}$, which show the values of 0.184 and $1.250 \mathrm{~cm}^{3} / \mathrm{cm}^{3}$, respectively The reason for this result might be that the soil volumetric moisture content $(\theta)$ is multiplied by the soil depth and because the obtained tillage depth of $25 \mathrm{~cm}$ had high moisture content compared with tillage depths of $45 \mathrm{~cm}$ and $15 \mathrm{~cm}$. The results obtained show significant differences between the numbers of Plastic Films (PF) in $\theta$. The soil of the double-plastic film resulted in a higher value of $\theta$ $\left(0.231 \mathrm{~cm}^{3} / \mathrm{cm}^{3}\right)$ and a lower value of $0.103 \mathrm{~cm}^{3} / \mathrm{cm}^{3}$ with the without-plastic film. The reason for this finding might be that the soil of the double-plastic film exhibited higher moisture content compared with other treatments because double-plastic film reduces the amount of water lost from evaporation compared with single-plastic film and without-plastic film. Surprisingly, no differences were found between fertilizer types on volumetric moisture content $(\theta)$. Statistical significance was evaluated at $\mathrm{p} \leq 0.05$.

The results also showed that there was a significant positive correlation between Tillage Depth (TD) and number of Plastic Films (PF) with volumetric moisture content $(\theta)$. TD $25 \mathrm{~cm}$ and soil of the double-plastic film obtained the highest value of $\theta$ $\left(0.242 \mathrm{~cm}^{3} / \mathrm{cm}^{3}\right)$; while the lowest value of 0.026 $\mathrm{cm}^{3} / \mathrm{cm}^{3}$ resulted from the interaction between TD 15 $\mathrm{cm}$ and the without -plastic film. 
Table 3. Effect of tillage depth, number of plastic films and fertilizer type on porosity (\%)

\begin{tabular}{|c|c|c|c|c|c|}
\hline \multirow[b]{3}{*}{ Tillage depth $(\mathrm{cm})$} & \multirow{3}{*}{$\begin{array}{l}\text { Number of Plastic } \\
\text { Films (PF) }\end{array}$} & \multicolumn{4}{|c|}{ Average $\Phi(\%)$ on interaction triple } \\
\hline & & \multicolumn{3}{|c|}{ Fertilizer Type (FT) } & \multirow{2}{*}{$\begin{array}{l}\text { Interaction the tillage } \\
\text { Depth and number of } \\
\text { plastic films }\end{array}$} \\
\hline & & Chemical & Organic & Without & \\
\hline \multirow[t]{4}{*}{15} & Single & 52.83 & 53.96 & 52.45 & 52.57 \\
\hline & Double & 53.2 & 54.71 & 52.83 & 53.70 \\
\hline & Without-plastic film & 51.69 & 52.45 & 50.90 & 52.06 \\
\hline & Single & 51.32 & 52.45 & 50.94 & 51.82 \\
\hline \multirow[t]{2}{*}{25} & Double & 52.83 & 53.58 & 50.94 & 52.82 \\
\hline & Without-plastic film & 52.83 & 53.58 & 50.94 & 50.94 \\
\hline \multirow[t]{3}{*}{45} & Single & 51.69 & 52.45 & 48.67 & 50.81 \\
\hline & Double & 52.83 & 53.20 & 50.18 & 51.19 \\
\hline & Without-plastic film & 48.3 & 47.92 & 47.92 & 48.92 \\
\hline Average of fertilizer & & 51.73 & 52.57 & 50.64 & LSD 0.05 \\
\hline Tillage depth (cm) & $\begin{array}{l}\text { Fertilizers Type } \\
\text { (FT) }\end{array}$ & \multicolumn{2}{|c|}{$\begin{array}{l}\text { Average } \Phi(\%) \text { on } \\
\text { Interaction tillage } \\
\text { depth and fertilizer type }\end{array}$} & $\begin{array}{l}\text { Average } \Phi(\% \\
\text { on the Tillage } \\
\text { Depth (TD) }\end{array}$ & $\begin{array}{l}\text { Tillage depth }=0.855, \\
\text { Number of plastic films } \\
=0.889 \\
\text { Fertilizer type }=0.936\end{array}$ \\
\hline 15 & $\begin{array}{l}\text { Chemical } \\
\text { Organic } \\
\text { Without }\end{array}$ & \multicolumn{2}{|l|}{$\begin{array}{l}53.58 \\
51.68\end{array}$} & 52.78 & $\begin{array}{l}\text { Tillage depth } \times \text { number } \\
\text { of plastic film }=0.646 \\
\text { Tillage depth } \times \text { fertilizer }\end{array}$ \\
\hline 25 & $\begin{array}{l}\text { Chemical } \\
\text { Organic } \\
\text { Without }\end{array}$ & \multicolumn{2}{|l|}{$\begin{array}{l}52.57 \\
51.57\end{array}$} & 51.86 & $\begin{array}{l}\text { Type }=0.823 \\
\text { Number of plastic film } \times \\
\text { Fertilizer type }=0.869\end{array}$ \\
\hline 45 & $\begin{array}{l}\text { Chemical } \\
\text { Organic } \\
\text { Without }\end{array}$ & $\begin{array}{l}50.81 \\
52.07 \\
48.04\end{array}$ & & 50.3 & $\begin{array}{l}\text { Tillage depth } \times \text { number } \\
\text { of Plastic film } \times \text { fertilizer } \\
\text { Type }=0.369\end{array}$ \\
\hline $\begin{array}{l}\text { Number of } \\
\text { Plastic Films (PF) }\end{array}$ & $\begin{array}{l}\text { Fertilizer Type } \\
(\mathrm{FT})\end{array}$ & \multicolumn{2}{|c|}{$\begin{array}{l}\text { Average } \Phi(\%) \text { on } \\
\text { interaction the number } \\
\text { of plastic films and } \\
\text { fertilizer type }\end{array}$} & \multicolumn{2}{|c|}{$\begin{array}{l}\text { Average } \Phi(\%) \text { on the } \\
\text { number of plastic films }\end{array}$} \\
\hline Single & $\begin{array}{l}\text { Chemical } \\
\text { Organic } \\
\text { Without }\end{array}$ & $\begin{array}{l}51.94 \\
52.94 \\
50.68\end{array}$ & & 51.82 & \\
\hline Double & $\begin{array}{l}\text { Chemical } \\
\text { Organic } \\
\text { Without }\end{array}$ & $\begin{array}{l}152,95 \\
53.83 \\
51.31\end{array}$ & & 52.70 & \\
\hline Without-plastic film & $\begin{array}{l}\text { Chemical } \\
\text { Organic } \\
\text { Without }\end{array}$ & $\begin{array}{l}50.31 \\
51.06 \\
49.95\end{array}$ & & 50.43 & \\
\hline
\end{tabular}

In addition, it can be seen from the data in Table 4 that the interaction TD $25 \mathrm{~cm}$ and Without Fertilizer (WF) type obtained the highest value of $\theta(0.203$ $\left.\mathrm{cm}^{3} / \mathrm{cm}^{3}\right)$, lowest value $\left(0.124 \mathrm{~cm}^{3} / \mathrm{cm}^{3}\right)$ when interaction TD $15 \mathrm{~cm}$ and Without Fertilizer (WF) type. The interaction between number of Plastic Films (PF) and Fertilizer Type (FT) showed significant differences between a combination of double-plastic and Without Fertilizer (WF) to other treatments, obtained the highest value of $\theta\left(0.238 \mathrm{~cm}^{3} / \mathrm{cm}^{3}\right)$; while the lowest value of $\theta$ showed at interaction between soil without-plastic film and without fertilizer type $\left(0.085 \mathrm{~cm}^{3} / \mathrm{cm}^{3}\right)$.

Furthermore, this finding confirms that triple interaction causes significant difference in the value of $\theta$. The obtained interaction between TD $25 \mathrm{~cm}$, soil of the double-plastic film and Without Fertilizer (WF) type at the highest value $\left(0.262 \mathrm{~cm}^{3} / \mathrm{cm}^{3}\right)$ and the lowest value $\left(0.006 \mathrm{~cm}^{3} / \mathrm{cm}^{3}\right)$ resulted in triple interaction TD $15 \mathrm{~cm}$, soil of the withoutplastic film and Organic Fertilizer (OF) type.

\section{Influence of the Studied Factors on Soil Thermal} Diffusivity $\left(\mathrm{m}^{2} / \mathrm{sec}\right)$

Table 5 shows the results obtained from the preliminary analysis of the influence of soil Tillage Depth (TD), number of Plastic Films (PF) and Fertilizer Type (FT) on soil thermal diffusivity $(D)$. The results showed a significant effect of TD on the $D$. The highest value of $D$ $\left(1.94 \times 10^{-6} \mathrm{~m}^{2} / \mathrm{sec}\right)$ was obtained at TD $45 \mathrm{~cm}$ in comparison with the others $(25$ and $15 \mathrm{~cm})$, which showed the values $9.65 \times 10^{-7}$ and $1.24 \times 10^{-6} \mathrm{~m}^{2} / \mathrm{sec}$, respectively. 
Table 4. Shows the effect of tillage depth, number of plastic films and fertilizer type on soil volumetric moisture $\mathrm{content}\left(\mathrm{cm}^{3} / \mathrm{cm}^{3}\right)$

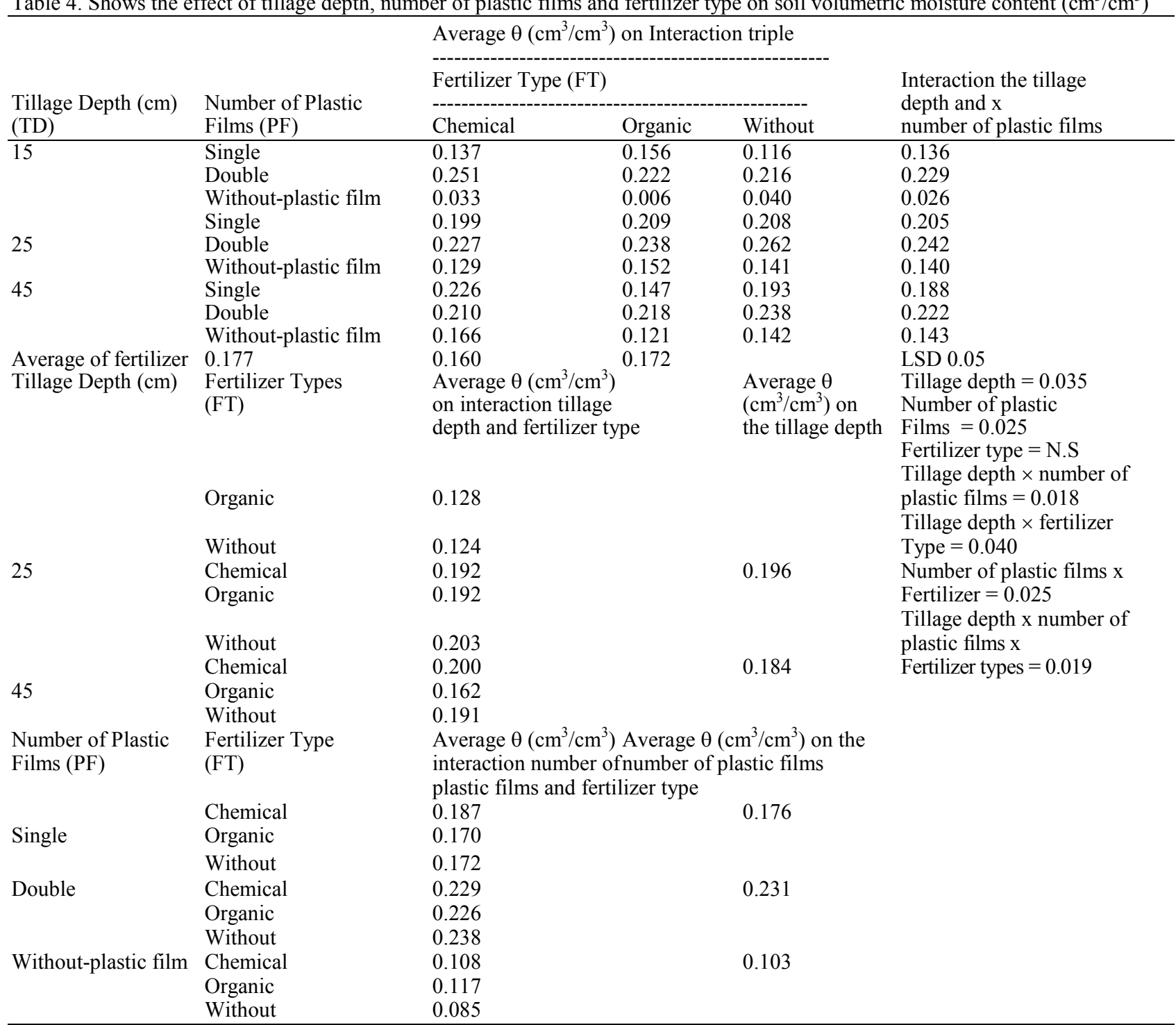

The reason for this result might be because the TD $45 \mathrm{~cm}$ exhibited higher bulk density $\rho b$, compared with TD 25 and $15 \mathrm{~cm}, D$ is increased by increasing $\rho b$. This finding agrees with the findings of (Levy and Schmidt, 2016; Miyajima et al., 2015; Usowicz et al. 2016). The number of Plastic Films (PF) showed significant differences in $D$. The soil of the without-plastic films showed the highest value of $D$ at $4.44 \times 10^{-6} \mathrm{~m}^{2} / \mathrm{sec}$ in comparison with soil covered by single-plastic films and double-plastic film, which showed the values $1.90 \times 10^{-6}$ and $7.76 \times 10^{-7} \mathrm{~m}^{2} / \mathrm{sec}$, respectively. The reason for this finding might be because the soil in the without-plastic film presented higher bulk density $(\rho b)$,which led to increased $D$, one of the most common factors to impact on soil thermal diffusivity. These results support the findings of (Tong et al., 2017).

The results showed no significant difference between Fertilizer Types (FT) on soil thermal diffusivity $(D)$. From the data in Table 5, strong evidence of $D$ was found at the interaction between the Tillage Depth (TD) and the number of soil- plastic film on the soil thermal diffusivity $(D)$. The TD15 cm and without-plastic film showed the higher value of $D\left(1.09 \times 10^{-5} \mathrm{~m}^{2} / \mathrm{sec}\right)$ and the lower value $D\left(5.86 \times 10^{-7}\right.$ $\mathrm{m}^{2} / \mathrm{sec}$ ) was obtained at the interaction of TD $15 \mathrm{~cm}$ and the double-plastic film. Furthermore, it can be seen from the data that there was a significant positive correlation between Tillage Depth (TD) and Fertilizer Type (FT), indicating interaction at TD $45 \mathrm{~cm}$ and Organic Fertilizer (OF) obtained the highest $D$ of $1.09 \times 10^{-6} \mathrm{~m}^{2} / \mathrm{sec}$. The lowest value $\left(9.63 \times 10^{-7} \mathrm{~m}^{2} / \mathrm{sec}\right)$ resulted from interaction at TD $25 \mathrm{~cm}$ and Chemical Fertilizer (CF) type. Interaction between the number of Plastic Films (PF) and Fertilizer Types (FT) on soil thermal diffusivity $(D)$, the single-plastic film and the Organic Fertilizer (OF) type showed the highest value of $D\left(1.00 \times 10^{-6} \mathrm{~m}^{2} / \mathrm{sec}\right)$ and the lowest value $\left(8.27 \times 10^{-7} \mathrm{~m}^{2} / \mathrm{sec}\right)$ obtained at soil double-plastic film and without Fertilizer Type (WF). 


\begin{tabular}{|c|c|c|c|c|c|}
\hline \multirow{2}{*}{$\begin{array}{l}\text { Tillage Depth }(\mathrm{cm}) \\
\text { (TD) }\end{array}$} & \multirow{2}{*}{$\begin{array}{l}\text { Number of Plastic } \\
\text { Films (PF) }\end{array}$} & \multicolumn{3}{|c|}{$\begin{array}{l}\text { Average } D\left(\mathrm{~m}^{2} / \mathrm{s}\right) \text { on interaction triple } \\
\text { Fertilizer Type (FT) }\end{array}$} & \multirow{2}{*}{$\begin{array}{l}\text { Interaction } \\
\text { the tillage depth and } \\
\text { number of plastic films }\end{array}$} \\
\hline & & Chemical & Organic & Without & \\
\hline \multirow[t]{4}{*}{15} & Single & $1.14 \times 10^{-6}$ & $1.01 \times 10^{-6}$ & $1.20 \times 10^{-6}$ & $1.12 \times 10^{-6}$ \\
\hline & Double & $7.90 \times 10^{-8}$ & $8.10 \times 10^{-7}$ & $8.70 \times 10^{-7}$ & $5.86 \times 10^{-7}$ \\
\hline & Without-plastic film & $4.56 \times 10^{-6}$ & $2.48 \times 10^{-5}$ & $3.47 \times 10^{-6}$ & $1.09 \times 10^{-5}$ \\
\hline & Single & $9.50 \times 10^{-7}$ & $9.00 \times 10^{-7}$ & $9.40 \times 10^{-7}$ & $9.30 \times 10^{-7}$ \\
\hline \multirow[t]{2}{*}{25} & Double & $8.50 \times 10^{-7}$ & $8.11 \times 10^{-7}$ & $8.29 \times 10^{-7}$ & $8.30 \times 10^{-7}$ \\
\hline & Without-plastic film & $1.09 \times 10^{-6}$ & $1.16 \times 10^{-6}$ & $1.16 \times 10^{-6}$ & $1.13 \times 10^{-6}$ \\
\hline \multirow[t]{3}{*}{45} & Single & $8.83 \times 10^{-6}$ & $1.10 \times 10^{-6}$ & $1.05 \times 10^{-6}$ & $3.66 \times 10^{-6}$ \\
\hline & Double & $9.80 \times 10^{-7}$ & $8.60 \times 10^{-7}$ & $9.00 \times 10^{-7}$ & $9.13 \times 10^{-7}$ \\
\hline & Without-plastic film & $1.16 \times 10^{-6}$ & $1.33 \times 10^{-6}$ & $1.25 \times 10^{-6}$ & $1.24 \times 10^{-6}$ \\
\hline \multirow{2}{*}{$\begin{array}{l}\text { Average of fertilizer type } \\
\text { Tillage Depth }(\mathrm{cm}) \\
\text { (TD) }\end{array}$} & & $2.18 \times 10^{-6}$ & $3.64 \times 10^{-6}$ & $1.29 \times 10^{-6}$ & LSD 0.05 \\
\hline & $\begin{array}{l}\text { Fertilizers Types } \\
\text { (FT) }\end{array}$ & $\begin{array}{l}\text { Average } D \\
\text { interaction } \\
\text { depth and } 1\end{array}$ & $\begin{array}{l}\text { on } \\
\left(\mathrm{m}^{2} / \mathrm{s}\right) \text { on the } \\
\text { er types }\end{array}$ & $\begin{array}{l}\text { Average } D \\
\text { tillage depth }\end{array}$ & $\begin{array}{l}\text { Tillage depth }=2.677 \times 10^{-6} \\
\text { Number of plastic films } \\
=2.641 \times 10^{-6} \text { Fertilizer }\end{array}$ \\
\hline \multirow[t]{3}{*}{15} & Chemical & $1.92 \times 10^{-6}$ & & $1.24 \times 10^{-6}$ & Types $=$ N.S \\
\hline & Organic & $8.83 \times 10^{-6}$ & & & Plastic films $=2.44 \times 10^{-6}$ \\
\hline & Without & $1.85 \times 10^{-6}$ & & & Tillage Depth X Fertilizer \\
\hline \multirow[t]{4}{*}{25} & Chemical & $9.63 \times 10^{-7}$ & & $9.65 \times 10^{-7}$ & Types $=2.811 \times 10^{-6}$ \\
\hline & Organic & $9.56 \times 10^{-7}$ & & & Number of plastic films $X$ \\
\hline & Without & $1.84 \times 10^{-7}$ & & & Fertilizer types $=2.770 \times 10^{-6}$ \\
\hline & Chemical & $3.65 \times 10^{-6}$ & & $1.94 \times 10^{-6}$ & Tillage Depth X Number of \\
\hline \multirow[t]{3}{*}{45} & Organic & $1.09 \times 10^{-6}$ & & & Plastic Films X Fertilizer \\
\hline & Without & $1.06 \times 10^{-6}$ & & & Types $=6.28 \times 10^{-9}$ \\
\hline & Chemical & $3.64 \times 10^{-6}$ & & & \\
\hline $\begin{array}{l}\text { Number of Plastic } \\
\text { Films (PF) }\end{array}$ & $\begin{array}{l}\text { Fertilizer Types } \\
\text { (FT) }\end{array}$ & $\begin{array}{l}\text { Average } D \\
\text { interaction } \\
\text { of plastic f } \\
\text { fertilizer ty }\end{array}$ & & $\begin{array}{l}\text { Average } D(\mathrm{n} \\
\text { number of } \mathrm{pl}\end{array}$ & $\begin{array}{l}\text { s) on the } \\
\text { ic films }\end{array}$ \\
\hline \multirow[t]{3}{*}{ Single } & Chemical & $3.64 \times 10^{-6}$ & & $1.90 \times 10^{-6}$ & \\
\hline & Organic & $1.00 \times 10^{-6}$ & & & \\
\hline & Without & $1.06 \times 10^{-6}$ & & & \\
\hline \multirow[t]{3}{*}{ Double } & Chemical & $6.36 \times 10^{-7}$ & & $7.76 \times 10^{-7}$ & \\
\hline & Organic & $8.27 \times 10^{-7}$ & & & \\
\hline & Without & $1.96 \times 10^{-6}$ & & & \\
\hline \multirow[t]{3}{*}{ Without-plastic film } & Chemical & $2.27 \times 10^{-6}$ & & $4.44 \times 10^{-6}$ & \\
\hline & Organic & $9.09 \times 10^{-6}$ & & & \\
\hline & Without & $1.96 \times 10^{-6}$ & & & \\
\hline
\end{tabular}

Interestingly, the triple interaction was observed at soil thermal diffusivity $(D)$. The highest value of $D$ at $2.48 \times 10^{-5} \mathrm{~m}^{2} / \mathrm{se} \mathrm{cw}$ as obtained as a result of interaction of TD $15 \mathrm{~cm}$, without- plastic film and Organic Fertilizer (OF) type, while the lowest value $\left(7.90 \times 10^{-8} \mathrm{~m}^{2} / \mathrm{sec}\right)$ was obtained as a result of interaction of TD $15 \mathrm{~cm}$, doubleplastic film and Chemical Fertilizer (CF) type

\section{Conclusion}

This study presented an experimental investigation of soil solarisation technology on soil thermo-physical properties. The results show significant differences in the following factors: Soil bulk density $(\rho b)$, porosity $(\Phi)$ and gravimetric water content $(\theta)$ and soil thermal diffusivity $(D)$. The results of this investigation show that the tillage depth of $15 \mathrm{~cm}$ produces lower values of $p b, \theta$ and $D\left(1.25 \mathrm{Mg} / \mathrm{cm}^{3}, 0.131 \mathrm{~cm}^{3} / \mathrm{cm}^{3}\right.$ and $1.24 \times 10^{-6}$ $\mathrm{m}^{2} / \mathrm{sec}$, respectively) and a higher value of $\Phi(52.78 \%)$. Furthermore, $D$ and $p b$ are directly proportional. There was a significant positive correlation between the number of plastic film and parameters studied, the soil double plastic film was obtained lower values of $p b$ and $D$ for soil $\left(1.253 \mathrm{Mg} / \mathrm{cm}^{3,} 7.76 \times 10^{-7} \mathrm{~m}^{2} / \mathrm{sec}\right)$. However, it recorded higher values for $\Phi$ and $\theta$ for soil (52.70\% and $0.231 \mathrm{~cm}^{3} / \mathrm{cm}^{3}$, respectively). Furthermore, It was also shown that significant differences between the types of fertilizers on $p b$. Organic fertilizer obtained a lower value of $p b\left(1.256 \mathrm{Mg} / \mathrm{m}^{3}\right)$, compared with chemical fertilizer and without fertilizer $\left(1.277\right.$ and $1.307 \mathrm{Mg} / \mathrm{m}^{3}$, 
respectively). On the other hand the results of this study indicate no significant differences in the fertilizer type on $D$ and $\theta$. A positive correlation was found in the interaction between the studied factors in the parameters. Furthermore, $D$ increased with increasing soil bulk density $(p b)$ and tillage depth. Also, soil thermal diffusivity $(D)$ was observed to increase with increasing $\rho b$ and TD.

\section{Acknowledgment}

We thank Will Gates (Institute for Frontier Materials, Deakin University. Melbourne, Australia) for comments that greatly improved the manuscript.

\section{Author's Contributions}

Ahmed Abed Gatea Al-Shammary: Participated in all experiments, coordinated the data-analysis and contributed to the writing of the manuscript.

Abbas Kouzani: Participated in coordinated the dataanalysis and contributed to the writing of the manuscript.

Akif Kaynak, Sui Yang and Michael Norton: Participated in writing of the manuscript

\section{Ethics}

This article is original and contains unpublished material. All of the authors have read and approved the manuscript and no ethical issues involved.

\section{References}

Al-Shammary, A.A.G. and J.N.A. Al-Sadoon, 2014. 'Influence of tillage depth, soil mulching systems and fertilizers on some thermal properties of silty clay soil. Eur. J. Agric. Forestry Res., 2: 1-16.

Al-Shammary, A.A.G., J.N.A. Al-Sadoon and N.R. Lahmod, 2016. Influence of the soil solarization management and fertilizer on soil temperature under different soil tillage systems. J. Agric. Sci., 8: 98-98.

Alam, M. and N. Salahin, 2013. Changes in soil physical properties and crop productivity as influenced by different tillage depths and cropping patterns. Bangladesh J. Agric. Res., 38: 289-99.

Alrtimi, A., M. Rouainia and S. Haigh, 2016. Thermal conductivity of a sandy soil. Applied Thermal Eng., 106: 551-60.

An, K., W. Wang, Y. Zhao, W. Huang and L. Chen et al., 2016. Estimation from soil temperature of soil thermal diffusivity and heat flux in sub-surface layers. Boundary-Layer Meteorol., 158: 473-88.

Andújar Márquez, J.M., M.Á. Martínez Bohórquez and S. Gómez Melgar, 2016. Ground thermal diffusivity calculation by direct soil temperature measurement.
Application to very low enthalpy geothermal energy systems. Sensors, 16: 306-306.

Bennett, J.M., S.D. Roberton, T.A. Jensen, D.L. Antille and J. Hall, 2017. A comparative study of conventional and controlled traffic in irrigated cotton: I. Heavy machinery impact on the soil resource. Soil Tillage Res., 168: 143-54.

Tamminen, P. and M. Starr, 1994. Bulk density of forested mineral soils. Silva Fennica. DOI: 10.14214/sf.a9162

Celik, I., H. Gunal, M. Budak and C. Akpinar, 2010. Effects of long-term organic and mineral fertilizers on bulk density and penetration resistance in semiarid Mediterranean soil conditions. Geoderma, 160: 236-43.

Cerdà, A., Ó. González-Pelayo, A. Giménez-Morera, A. Jordán and P. Pereira et al., 2016. Use of barley straw residues to avoid high erosion and runoff rates on persimmon plantations in Eastern Spain under low frequency-high magnitude simulated rainfall events. Soil Res., 54: 154-65.

Chaudhari, P.R., D.V. Ahire, V.D. Ahire, M. Chkravarty and S. Maity, 2013. Soil bulk density as related to soil texture, organic matter content and available total nutrients of Coimbatore soil. Int. J. Scientific Res. Public., 3: 1-8.

Conant, R.T., M.G. Ryan, G.I. Ågren, H.E. Birge and E.A. Davidson et al., 2011. Temperature and soil organic matter decomposition rates-synthesis of current knowledge and a way forward. Global Change Biol., 17: 3392-404.

Dec, D., J. Dörner and R. Horn, 2009. Effect of soil management on their thermal properties. Revista De La Ciencia Del Suelo Y Nutrición Vegetal, 9: 26-39.

Evett, S.R., N. Agam, W.P. Kustas, P.D. Colaizzi and R.C. Schwartz, 2012. Soil profile method for soil thermal diffusivity, conductivity and heat flux: Comparison to soil heat flux plates. Adv. Water Resources, 50: 41-54.

Gan, L., X. Peng, S. Peth and R. Horn, 2012. Effects of grazing intensity on soil thermal properties and heat flux under Leymus chinensis and Stipa grandis vegetation in Inner Mongolia, China. Soil Tillage Res., 118: 147-58.

Genesio, L., F. Miglietta, E. Lugato, S. Baronti and M. Pieri et al., 2012. Surface albedo following biochar application in durum wheat. Environ. Res. Lett., 7: 014025-014025.

Gnatowski, T., 2009. Analysis of thermal diffusivity data determined for selected organic topsoil layer. Annals Warsaw University Life Sciences-SGGW. Land Reclamat., 41: 95-107.

Grunwald, D., M. Kaiser, S. Junker, S. Marhan and H.P. Piepho et al., 2017. Influence of elevated soil temperature and biochar application on organic matter associated with aggregate-size and density fractions in an arable soil. Agric. Ecosyst. Environ., 241: 79-87. 
Hillel, D., 1998. Environmental Soil Physics: Fundamentals, Applications and Environmental Considerations. 1st Edn., Academic Press, San Diego, ISBN-10: 0080544150, pp: 771.

$\mathrm{Hu}, \mathrm{G} ., \mathrm{L}$. Zhao, X. Wu, R. Li and T. Wu et al., 2016. New Fourier-series-based analytical solution to the conduction-convection equation to calculate soil temperature, determine soil thermal properties, or estimate water flux. Int. J. Heat Mass Transfer, 95: 815-23.

Ingman, M., M.V. Santelmann and B. Tilt, 2015. Agricultural water conservation in China: Plastic mulch and traditional irrigation. Ecosy. Health Sustainability, 1: 1-11.

Jabran, K., M. Hussain, S. Fahad, M. Farooq and A.A. Bajwa et al., 2016. Economic assessment of different mulches in conventional and water-saving rice production systems. Environ. Sci. Pollut. Res., 23: 9156-63.

Jabro, J.D., W.M. Iversen, W.B. Stevens, R.G. Evans and M.M. Mikha et al., 2016. Physical and hydraulic properties of a sandy loam soil under zero, shallow and deep tillage practices. Soil Tillage Res., 159: 67-72.

Jiang, X.J., W. Liu, E. Wang, T. Zhou and P. Xin, 2017. Residual plastic mulch fragments effects on soil physical properties and water flow behavior in the Minqin Oasis, northwestern China. Soil Tillage Res., 166: 100-7.

Kader, M., M. Senge, M. Mojid and K. Ito, 2017. Recent advances in mulching materials and methods for modifying soil environment. Soil Tillage Res., 168: 155-66.

Karuma, A., P. Mtakwa, N. Amuri, C.K. Gachene and P. Gicheru, 2014. Tillage effects on selected soil physical properties in a maize-bean intercropping system in Mwala District, Kenya. Int. Scholarly Res. Notices.

Keesstra, S., P. Pereira, A. Novara, E.C. Brevik and C. Azorin-Molina et al., 2016. Effects of soil management techniques on soil water erosion in apricot orchards. Sci. Total Environ., 551: 357-66.

Kersten, M.S., 1949. Thermal properties of soils.

Krishna, K.R., 2016. Push Button Agriculture: Robotics, Drones, Satellite-Guided Soil and Crop Management. 1st Edn., Apple Academic Press, Oakville, ISBN-10: 1771883057, pp: 470.

Kroetsch, D. and C. Wang, 2007. Particle Size Distribution. Soil Sampling and Methods of Analysis. 2nd Edn., CRC Press.

Levy, J.S. and L.M. Schmidt, 2016. Thermal properties of Antarctic soils: Wetting controls subsurface thermal state. Antarctic Sci.

Li, D., J. Fan, X. Zhang, X. Xu and N. He et al., 2016. Hydrolase kinetics to detect temperature-related changes in the rates of soil organic matter decomposition. Eur. J. Soil Biol.

Li, R., R. Tao, N. Ling and G. Chu, 2017. Chemical, organic and bio-fertilizer management practices effect on soil physicochemical property and antagonistic bacteria abundance of a cotton field: Implications for soil biological quality. Soil Tillage Res., 167: 30-8.

Liang, H., K. Hu, W. Qin, Q. Zuo and Y. Zhang, 2017. Modelling the effect of mulching on soil heat transfer, water movement and crop growth for ground cover rice production system. Field Crops Res., 201: 97-107.

Logsdon, S.D., T.R. Green, J.V. Bonta, M.S. Seyfried and S.R Evett, 2010. Comparison of electrical and thermal conductivities for soils from five states. Soil Sci., 175: 573-8.

Lu, N. and Y. Dong, 2015. Closed-form equation for thermal conductivity of unsaturated soils at room temperature. J. Geotech. Geo Environ. Eng., 141: 04015016-04015016.

Łydżba, D., A. Różański, M. Rajczakowska and D. Stefaniuk, 2016. Random checkerboard based homogenization for estimating effective thermal conductivity of fully saturated soils. J. Rock Mechan. Geotech. Eng.

Mahdavi, S.M., M.R. Neyshabouri, H. Fujimaki and A.M. Heris, 2017. Coupled heat and moisture transfer and evaporation in mulched soils. Catena, 151: 34-48.

Makarychev, S.V. and A.G. Bolotov, 2017. Conductive and steam-diffuse constituents of thermo transfer in different soil moisture contents: case study of the Altai Region's soils. Eurasian J. Soil Sci., 6: 44-44.

Merante, P., C. Dibari, R. Ferrise, B. Sánchez and A. Iglesias et al., 2017. Adopting soil organic carbon management practices in soils of varying quality: Implications and perspectives in Europe. Soil Tillage Res., 165: 95-106.

Miyajima, S., N. Uoi, T. Murata, M. Takeda and W. Morishima et al., 2015, 'Effect of structural modification on heat transfer through man-made soils in urban green areas. Soil Sci. Plant Nutrit., 61: 70-87.

Mondal, S., G. Padmakumar, V. Sharma, D.N. Singh and M.S. Baghini, 2016. A methodology to determine thermal conductivity of soils from flux measurement. Geomechan. Geoeng, 11: 73-85.

Moreno, M.M., A. Cirujeda, J. Aibar and C. Moreno, 2016. Soil thermal and productive responses of biodegradable mulch materials in a processing tomato (Lycopersicon esculentum Mill.) crop. Soil Res., 54: 207-15.

Mutetwa, M. and T. Mtaita, 2014. Effects of mulching and fertilizer sources on growth and yield of onion. J. Glob. Innov. Agric. Soc. Sci., 2: 102-6. 
Smith, K.A., 2000. Soil and Environmental Analysis: Physical Methods, Revised and Expanded. 2nd Edn., CRC Press, ISBN-10: 0203908600, pp: 656.

Pires, L.F., J.A. Borges, J.A. Rosa, M. Cooper and R.J. Heck et al., 2017. Soil structure changes induced by tillage systems. Soil Tillage Res., 165: 66-79.

Pramanik, P., K. Bandyopadhyay, D. Bhaduri, R. Bhatacharyya and P. Aggarwal, 2015. Effect of mulch on soil thermal regimes-A review. Int. J. Agric. Environ. Biotechnol., 8: 645-645.

Qin, W., C. Hu and O. Oenema, 2015. Soil mulching significantly enhances yields and water and nitrogen use efficiencies of maize and wheat: A metaanalysis. Scientific Rep., 5: 16210-16210.

Rajeev, P. and J. Kodikara, 2016. Estimating apparent thermal diffusivity of soil using field temperature time series. Geomechan. Geoeng., 11: 28-46.

Ravazzani, G., 2017. Open hardware portable dual-probe heat-pulse sensor for measuring soil thermal properties and water content. Comput. Electron. Agric., 133: 9-14.

Ravazzani, G., D. Curti, P. Gattinoni, S.D. Valentina and A. Fiorucci et al., 2015. Assessing groundwater contribution to streamflow of a large alpine river with heat tracer methods and hydrological Modelling. River Res. Applications.

Roxy, M., V. Sumithranand and G. Renuka, 2014. Estimation of soil moisture and its effect on soil thermal characteristics at Astronomical Observatory, Thiruvananthapuram, south Kerala. J. Earth Syst. Sci., 123: 1793-807.

Romaneckas, K., R. Romaneckiene and V. Pilipavicius, 2009. Non-chemical weed control in sugar beet crop under intensive and conservation soil tillage: I. Crop Weediness, Romaneckas Agronomy Res., 7: 457-464.

Tokoro, T., T. Ishikawa, S. Shirai and T. Nakamura, 2016. Estimation methods for thermal conductivity of sandy soil with electrical characteristics. Soils Foundat., 56: 927-36.
Tong, B., Z. Gao, R. Horton and L. Wang, 2017. Soil apparent thermal diffusivity estimated by conduction and by conduction-convection heat transfer models. J. Hydrometeorol., 18: 109-18.

Usowicz, B., J. Lipiec, M. Łukowski, W. Marczewski and J. Usowicz, 2016. The effect of biochar application on thermal properties and albedo of loess soil under grassland and fallow. Soil Tillage Res., 164: 45-51.

Usowicz, B., J. Lipiec, J.B. Usowicz and W. Marczewski, 2013. Effects of aggregate size on soil thermal conductivity: Comparison of measured and modelpredicted data. Int. J. Heat Mass Transfer., 57: 536-41.

Vogt, D.J., J.P. Tilley and R.L. Edmonds, 2015. Soil and Plant Analysis for Forest Ecosystem Characterization. 1st Edn., De Gruyter, Berlin, ISBN-10: 3110381761, pp: 240.

Williams, A., A.S. Davis, P.M. Ewing, A.S. Grandy and D.A. Kane et al., 2016. A comparison of soil hydrothermal properties in zonal and uniform tillage systems across the US Corn Belt. Geoderma, 273: 12-9.

Wu, Y., F. Huang, Z. Jia, X. Ren and T. Cai, 2017. Response of soil water, temperature and maize (Zea may L.) production to different plastic film mulching patterns in semi-arid areas of northwest China. Soil Tillage Res., 166: 113-21.

Xiukang, W., L. Zhanbin and X. Yingying, 2015. Effects of mulching and nitrogen on soil temperature, water content, nitrate-N content and maize yield in the Loess Plateau of China. Agric. Water Manage., 161: 53-64.

Zhang, T., G. Cai, S. Liu and A.J. Puppala, 2017. Investigation on thermal characteristics and prediction models of soils. Int. J. Heat Mass Transfer, 106: 1074-86.

Zhou, L., H. Feng, Y. Zhao, Z. Qi and T. Zhang et al., 2017. Drip irrigation lateral spacing and mulching affects the wetting pattern, shoot-root regulation and yield of maize in a sand-layered soil. Agric. Water Manage., 184: 114-23.

Appendix 1 Analysis of Variance (ANOVA table) for parameter studied

\begin{tabular}{llllllrlr}
\hline & $\begin{array}{l}\text { Source of } \\
\text { parameters }\end{array}$ & Variation & Df & $\begin{array}{l}\text { Mean } \\
\text { Anova SS }\end{array}$ & $\begin{array}{l}\text { F. } \\
\text { squares }\end{array}$ & Value & $\begin{array}{l}\text { R-Square } \\
\text { F.pr }\end{array}$ & $\begin{array}{l}\text { Coefficient of } \\
\text { variation }\end{array}$ \\
\hline Soil bulk density & TD & 2 & 0.0220 & 0.0110 & 17.19 & $<0.0001$ & & \\
& PF & 2 & 0.0231 & 0.0065 & 10.24 & 0.0009 & 0.792 & 1.979 \\
& FT & 2 & 0.0138 & 0.0069 & 10.80 & 0.0007 & & 2.051 \\
Soil porosity & TD & 2 & 28.644 & 14.322 & 12.70 & 0.0003 & & 18.627 \\
& PF & 2 & 17.676 & 8.8380 & 7.84 & 0.0031 & 0.744 & \\
Volumetric & FT & 2 & 19.533 & 9.7660 & 8.66 & 0.0020 & & 205.030 \\
moisture content & TD & 2 & 0.0218 & 0.0100 & 10.85 & 0.0006 & 0.8276 & \\
Soil & PF & 2 & 0.0742 & 0.0370 & 36.82 & $<0.0001$ & 0.2270 & \\
thermal & FT & 2 & 0.0007 & 0.0036 & 0.37 & 0.6980 & & \\
diffusivity & TD & 2 & $4.74 \times 10-11$ & $2.37 \times 10-11$ & 1.02 & 0.3770 & & \\
\hline
\end{tabular}


Appendix 2. Shows specifications of the tractor used

Specifications

Make

Engine type

Number of cylinder/Capacity No/cc

Max. engine speed (rated) rpm

Max. Torque Nm

Fuel tank capacity litres

Engine powerkW/hp

Standard rear tyres

Appendix 3. Shows specifications of implements

\begin{tabular}{lll}
\hline Specifications & Disc plough & Disc harrow \\
\hline Make & Turkey & Turkey \\
Width of cut $\mathrm{m}$ & 0.95 & $1.5 \mathrm{~m}$ \\
Number of units & 3 & $7 * 2$ \\
Tractor power requirement kw & $50-60$ & $50-60$ \\
\hline
\end{tabular}

\section{Nomenclature}

Thermo-Physical Properties TPP

Soil Physical Properties SPP

Soil Solarisation Technology SST

Soil-Mulching Systems SMS

Soil Mineral Composition SMC

Randomized Complete Block Design RCBD

Tillage Depth TD

Plastic Films PF

Soil bulk density $\quad P b$

Soil porosity $\Phi$

Soil volumetric moisture content $\theta$

Soil thermal diffusivity $D$

Soil thermal conductivity D

Soil volumetric heat capacity $\quad \mathrm{C}_{\mathrm{v}}$

Organic Fertilizer $O F$

Fertilizer Type $\quad F T$ 